\title{
Biocompatibility of Injectable Microspheres
}

\author{
Gottfried Lemperle* \\ Division of Plastic Surgery, University of California, USA
}

Received: January 16, 2018; Published: January 23, 2018

*Corresponding author: Gottfried Lemperle, Division of Plastic Surgery, University of California, Wolfsgangstr. 64, D-60322 Frankfurt am Main, USA, Tel: +49-69-1302-4217; Email: Lemperle8@aol.com

Abstract

The increasing need for long lasting injectable soft tissue fillers for the treatment of wrinkles and skin defects, gastric reflux, urinary and fecal incontinence, and other indications requires a critical discussion of biocompatibility based on science. Since biological fillers made of collagen will be absorbed over time, medium- and long-lasting biomaterials have been developed in recent years. Particles of irregular shape and rough surface structure tend to initiate severe and early foreign body reactions with scattered giant cells ("frustrated macrophages"). On the other hand, biologically inert microspheres with smooth surfaces are encapsulated by macrophages and fibrous tissue and will be kept in place. A review of the literature shows that most injected microspheres and particles of different chemical nature and a diameter of 20 to $65 \mu \mathrm{m}$ are phagocytosed by macrophages. Particles smaller than $20 \mu \mathrm{m}$ are also phagocytosed but are transported by macrophages to regional lymph nodes, liver and/or lungs. Since 1 gram of medium size microspheres of $40 \mu \mathrm{m}$ has a surface area twice as large as 1 gram of microspheres of $125 \mu \mathrm{m}$ in diameter, the stimulus for associated tissue in growth is doubled. Therefore, approximately $75 \%$ of the filler volume of a medium size microsphere implant consists of the body's own connective tissue, whereas only $40 \%$ of the filler volume encapsulating larger beads is made up of fibrous tissue.

Abbreviations: GERD: Gastro-Esophageal Reflux Disease; PI: Propidium Iodine; PSF: Polysulfone; RES: Reticulo-Endothelial System; SEM: Scanned Electron Microscopy; PMA: Polymethylacrylate; PLLA: Polylactic Acid; PTFE: Polytetrafluoroethylene

\section{Introduction}

Table 1: Classification of Biomaterials Used in Medicine.

\begin{tabular}{|c|c|}
\hline Classes & Forms \\
\hline Polymers & $\begin{array}{c}\text { Plastics, Membranes, Fibers, Fabrics, Rubbers, } \\
\text { Powders, Particles, Liquids }\end{array}$ \\
\hline Metals & Powders, Particles, Fibers \\
\hline Ceramics & Powders, Particles, Fibers, Solids, Cements \\
\hline Carbons & Machine Shapes, Coatings, Fibers \\
\hline Natural Tissues & Fibers, Reconstitutes \\
\hline Composites & Coatings, Fibers \\
\hline
\end{tabular}

Biomaterials have been used as implants for many decades in orthopedic, plastic, ENT, and ophthalmic surgery (Table 1). In search of an ideal soft tissue filler substance, a variety of biomaterials have been injected in form of micro particles [1] and microspheres [24] beneath wrinkles, into dermal defects, in patients with gastroesophageal reflux disease (GERD) [5], and into the urethra of Table 2: Injectable microspheres are used as wrinkle and bulking agents in skin depressions and stress urinary incontinence (SUI).

\begin{tabular}{|c|c|c|c|c|c|}
\hline Chemical Name & Trademark & Particle Size & Particle Range & Carrier & Ref. \\
\hline \multicolumn{6}{|c|}{ Permanent } \\
\hline Polydimethyl-siloxane particles & Macroplas tique, Bioplastique & $170 \mu \mathrm{m}$ & $16-409 \mu \mathrm{m}$ & $\begin{array}{c}\text { Polyvinyl-pyrolidone } \\
\text { PVP }\end{array}$ & {$[5]$} \\
\hline
\end{tabular}

patients with urinary incontinence [6]. The particles and spheres differed in chemical composition, surface structure, surface charge and particle size and stimulated different host reactions accordingly.

\section{Chemical Composition}

Practically, all hard materials such as metals, ceramics and polymers, many soft materials such as silicone gel, Teflon and hydro gels, as well as biological materials such as ivory, coral, soybean oil, silk, and catgut have been used as alloplastic substitutes for human tissue or as suture materials. However, synthetic polymers made up by far the broadest and most diverse class of biomaterials used. These synthetic polymers are available with a wide variety of compositions and properties and may be fabricated readily into complex shapes and structures. In addition, their surface may be modified physically, chemically and biochemically (Table 2). Water absorption in biomaterials is very important to the function of some polymers, such as hydrogels in soft contact lenses, PMA or dextran particles. 


\begin{tabular}{|c|c|c|c|c|c|}
\hline \multirow{4}{*}{$\begin{array}{l}\text { Polymethyl-methacrylate PMMA } \\
\text { microspheres }\end{array}$} & Artecoll & $40 \mu \mathrm{m}$ & $32-48 \mu \mathrm{m}$ & Bovine & {$[2]$} \\
\hline & Bellafill & $40 \mu \mathrm{m}$ & $32-48 \mu \mathrm{m}$ & collagen & [53] \\
\hline & Permafill(G125, U125) & $125 \mu \mathrm{m}$ & $120-130 \mu \mathrm{m}$ & & \\
\hline & Metacrill & $50 \mu \mathrm{m}$ & $20-80 \mu \mathrm{m}$ & $\begin{array}{l}\text { Carboxy-methyl- } \\
\text { cellulose }\end{array}$ & [3] \\
\hline $\begin{array}{c}\text { Carbon-coated zirkonium - } \\
\text { oxide spheres }\end{array}$ & Durasphere & $200 \mu \mathrm{m}$ & 212-500区m & beta-glucan & [60] \\
\hline $\begin{array}{c}\text { Hydroxy-ethylmethyl- acrylate } \\
\text { HEMA }\end{array}$ & Dermalive & $55 \mu \mathrm{m}$ & $10-130 \mu \mathrm{m}$ & hyaluronic acid HA & [70] \\
\hline \multicolumn{6}{|c|}{ Absorbables } \\
\hline Calcium-apatite & Radiesse, Coaptite & $100 \mu \mathrm{m}$ & $75-125 \mathrm{~mm}$ & Methyl-cellulose & [95] \\
\hline Polylactic acid PLLA & Sculptra & $46 \mu \mathrm{m}$ & $10-80 \mu \mathrm{m}$ & $\begin{array}{l}\text { Carboxy-cellulose } \\
\text { CMC }\end{array}$ & [95] \\
\hline Dextran & Deflux & $100 \mu \mathrm{m}$ & $80-120 \mu \mathrm{m}$ & hyaluronic acid & [72] \\
\hline Hyaluronic acid HA gel balls & Restylane, Juvederm, etc. & different products & $10-100 \mu \mathrm{m}$ & hyaluronic acid & [95] \\
\hline Polycapro-lactone PCL & Ellanse' $\mathrm{S}, \mathrm{M}$, and L & $40 \mu \mathrm{m}$ & $25-50 \mu \mathrm{m}$ & $\begin{array}{l}\text { Carboxy-methyl- } \\
\text { cellulose }\end{array}$ & \\
\hline
\end{tabular}

Certain water content may also lead to absorption of ions and other molecules such as enzymes, which cause biodegradation of the polymer, especially if it contains susceptible bonds [7]. Retractable sites such as $-\mathrm{OH}$, $-\mathrm{COOH}$, or $-\mathrm{NH} 2$ may be present on the polymer backbone, or may be introduced via free radical graft polymerization reaction. Such active compounds may also be electrostatically "bound" to the polymer by opposite charge or acid-base attractions of surrounding cells and fluids. In general, the behavior of particles is largely influenced by their particle character rather than by their chemical nature [8] (Figure 1). A description of the chemical nature of each particle would be beyond the scope of this review.

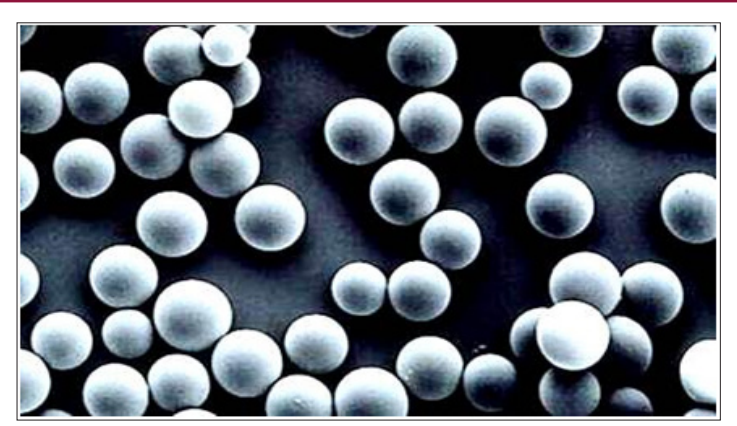

Figure 1: Cleaned PMMA-microspheres with apparently smooth surfaces.

\section{Surface Structure}

Although the chemical composition of the implant would seem to be of primary importance, its physical form is equally critical in determining biocompatibility $[9,10]$. A variety of physico-chemical factors affect phagocytosis, including particle size, shape, contact angles, collision factors, surface tension, and surface charge (Figure 2). A simple experiment [11] with rods of $1 \mathrm{~mm}$ in diameter, but different shapes implanted into rats showed that triangular polymer implants with sharp edges caused significantly higher cellular responses and acid phosphatase enzyme activity than square or round implants. Around implanted polyethylene disks with coarse surface in rats, a significant larger number of PI (propidium iodine stained) - positive cells with increased permeability were found in the tissue adjacent to the edges of the implant, when compared to implants with smooth surface [12].

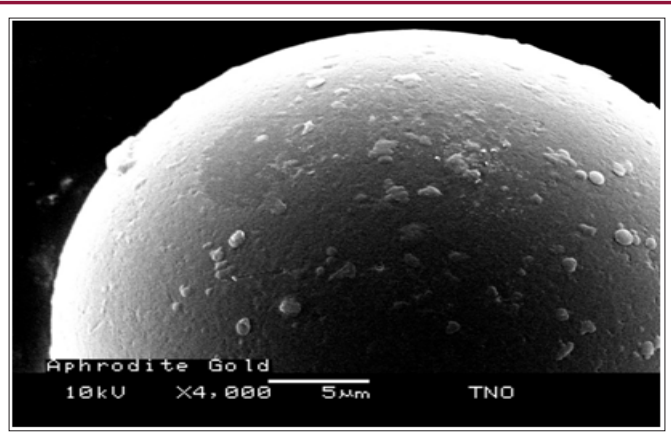

Figure 2: A closer look at the surface shows many irregularities and attached small particles, which are the secret of macrophage stimulation and encapsulation.

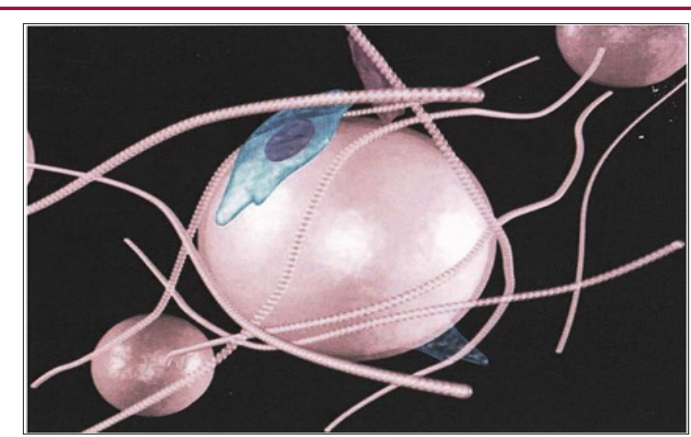

Figure 3: A microsphere with an absolute smooth surface absorbs proteins and becomes slowly covered with collagen fibers. The lack of macrophage engulfment allows "migration" according to gravity.

vThe surface topography seems to be the predominant factor relative to the induced tissue response. Taylor [9] demonstrated increased cell adhesion and increased enzyme release on textured Teflon ${ }^{\circledR}$ discs when compared to smooth Teflon ${ }^{\circledR}$ discs. The interfacial cells consisted of foreign body giant cells and macrophages in discs with rough surface, however, mainly 
of a fibrous capsule in smooth walled discs. At the beginning, macrophages enveloped the rough structures with inter-digitation of filopodia, frequently seen between macrophages near textured surfaces. A statistically significant difference in tissue stimulation existed also between rough and smooth particles [13]. The particles with rough surface (polysulfone PSF) were covered by foreign body giant cells, while smooth particles [2] were covered mainly by fibrous tissue (Figure 3).

Macrophages attach more rapidly to rough surfaces (Figure 2) than to smooth spherical microspheres [14-16]. Incubation of PMMA nanoparticles in serum, especially when complement inactivated prior to injection, reduced the uptake of radiolabeled microspheres by phagocytosis from the bloodstream into the RES [17]. Interestingly, no correlation between surface roughness and cell adhesion was noted in a study on a variety of metals and polymers [18]. Scanned electron microscopy (SEM) showed that fibroblast adhesion was highest in stainless steel and lowest in silicone rubber and polyethylene. Therefore, the composition and structure of surface molecules must play another important role in the attachment of macrophages and fibroblasts to smooth surfaces.

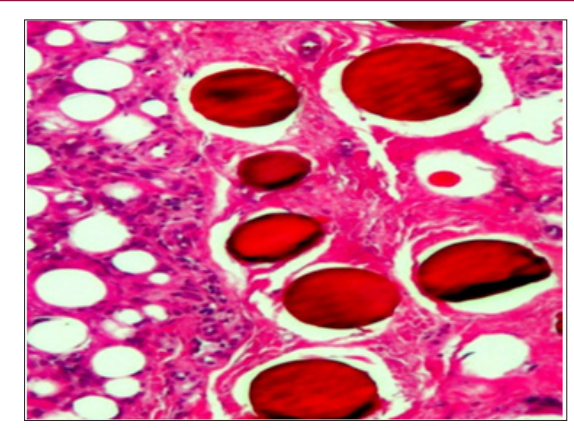

Figure 4: Embospheres (tris-acryl-gelatin) were found accidentally 8 years after injection into my forearm $6 \mathrm{~cm}$ proximal from the injection site, close to encapsulated PMMA-microspheres. There are still no macrophages attached due to their absolutely smooth surface.

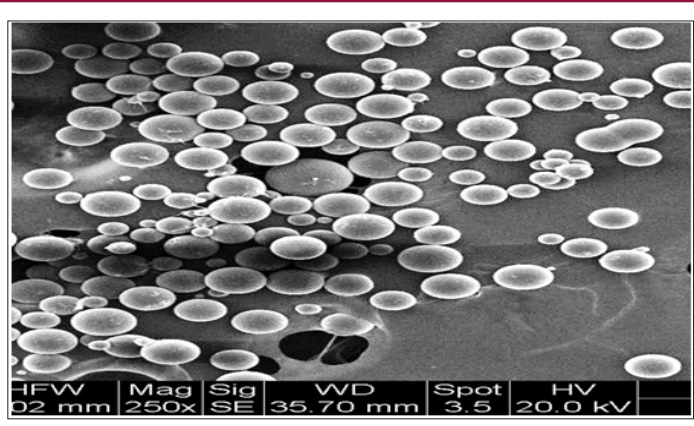

Figure 5: Brazilian PMMA-microspheres sieved from crude bone cement but not freed from small particles and microspheres $<20 \mu \mathrm{m}$.

\section{Impurities on Microspheres}

Microspheres from silicone, polyethylene, and tris-acryl gelatin can be produced with an absolutely smooth surface (Figure 4). They do not stimulate any foreign body reaction after injection into body tissues. On the other hand, it appears to be impossible to produce PMMA or PLLA or calcium microspheres without microscopic impurities, either attached to their surface (Figure 2) or small particles and microspheres $<20 \mu \mathrm{m}$ between the larger microspheres (Figure 5). Their number can be measured in a Coulter chamber or may be detected under a water droplet placed on PMMA-powder under the microscope (Figure 6). Impurities and smaller particles can be separated for example by wet sieving the crude bone cement powder through 2 micro-mesh sieves of $30 \mu \mathrm{m}$ and $50 \mu \mathrm{m}$ diameters. The still attached small particles can then be removed by intricate foam washing of the $40 \mu \mathrm{m}$ beads.

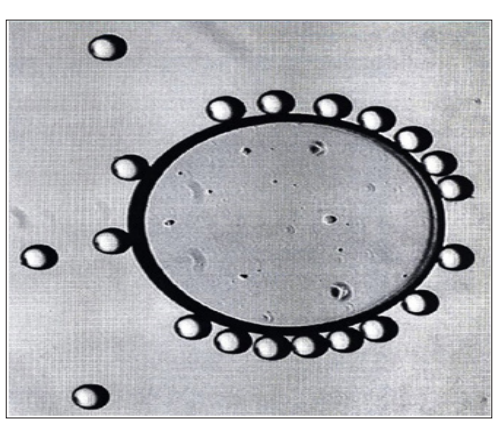

Figure 6: The focus of normal EM-pictures (Figure1) is higher than the ground: to detect impurities among the microspheres, one has to put a drop of water on the PMMA-powder, which focuses the ground.

In 2006, the US-FDA requested prior to the approval of Artefill $\AA$ that the content of small particles $<20 \mu$ m should be less than $1 \%$, or less than 1 particle among 100 microspheres of $40 \mu \mathrm{m}$ (Figure 1). Particles smaller than macrophages can stimulate their activity significantly because they can be transported to lymph nodes and lung - in contrast, larger particles and microspheres will remain at the injection site. Therefore, the rate reduction of foreign body granulomas associated with Artefill ${ }^{\circledR}$ and Artecoll ${ }^{\circledR}$ injections since 2006 [2] may be related to this strict and logical stipulation by the US-FDA.

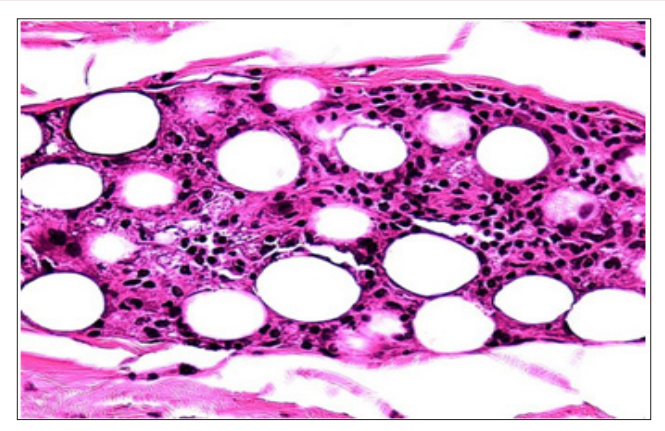

Figure 7: PMMA-microspheres stimulate macrophage and fibroblast activity from the beginning, which holds them in place.

\section{Surface Charge}

All living cells and most biomaterials possess a surface charge (zeta-potential) due to their chemical composition [19,20]. This may influence cell attachment to implanted materials $[18,21]$. The extent of cell adhesion is dependent on the surface tension of the substrate materials (silicone, PTFE, polystyrene, polyethylene etc.). Van Waals forces are the most important factors in determining the extent of cell adhesion to polymer surfaces. Absolom [22] 
demonstrated a decreased number of adherent granulocytes on different polymers with decreasing surface tension. With an increase of surface tension they found less absorption of proteins, which influence adhesion of cells. in vitro studies with different polymers indicate that hydrophilicity/hydrophobicity of the implant influences the type and strength of protein bands to the material [23]. PMMA particles, for instance, have a hydrophobic surface and therefore enhance protein synthetic activity and fibroblast proliferative capacity (Figure 7).

Polystyrene microspheres with hydrophobic surfaces, on the other hand, were more readily phagocytosed than those with hydrophilic surfaces [24]. There was no significant difference in phagocytosis between cationic and anionic surfaces when compared at zeta-potential of the same absolute value. The least phagocytosis was observed for cellulose and Embosphere (tris-acryl gelatin) microspheres with non-ionic hydrophilic surfaces (Figure 4). The addition of fetal calf serum to culture medium resulted in decrease in phagocytosis for all microspheres. Cell phagocytosis has frequently been noted to be similar to cell spreading on a solid substrate [25]. Cell surface charge does not vary significantly after cell death, however, dead cells exhibit different contact relations with various materials. Low-energy surfaces such as paraffin, silicone, and resins, allow only minimal cell spreading and result in a lack of adhesive bounding. Increased cell spreading observed on Teflon ${ }^{\circledR}$ particles reflects a departure of the surface energy towards the lower surface energy of the cell substrates [26].

The presence of an implant grossly changes the local dielectric environment, thus affecting local intermolecular interactions. Cells touching the implant may have their membrane potential altered due to the lack of physiological ions at the implant surface. Surface defects or lattice orientations on the implant surface can affect the tissue reaction as can residual surface charge or dipole orientation [27]. The conversion of the surface properties of metals and plastics, for example to exhibit the same critical surface tensions between 24 and 26 dynes per centimeter as natural endothelial cells, can minimize plasma protein denaturation [24]. However, little has been published on surface charges in vivo, since they are difficult to measure in living tissue [28] and may be subject to dramatic changes when in contact with surface charges of neighboring cells. On a surface with strong hydrophilic properties, an increase in cell adhesion has been demonstrated [23] in opposite to surfaces with less wetting properties. Negatively charged resin beads, such as the cation exchanger Sephadex®, induce bone formation, wound healing and giant cell invasion, whereas beads with no charges at all do not [29].

Increasing the negative surface charges of hydrophilic microspheres resulted in decreased phagocytosis [30]. Krukowski [31] implanted negatively charged dextran beads subperiosteally into rats and stimulated bone formation. Similarly applied positively charged or uncharged beads were non-osteogenic. All beads of 40-120 $\mu \mathrm{m}$ in diameter were ingested with multinucleated giant cells and separated by connective tissue (Figure 8). This study demonstrates that the expression of osteogenic potential is unrelated to the physical shape of the charged particles in that both beads and particles produced new bone. However, positively charged particles were consistently phagocytosed by prominent multinucleated giant cells. Negatively or not charged beads, on the other hand, were not typically associated with such typical macrophages. It is neither clear, why positive charges preferentially attract macrophages nor clear, why and how macrophages are activated by positive charges. In tissue culture, macrophages migrate towards positively charged particles $[3,4]$ and positively charged materials invoke a favorable wound-healing response in rat incisional wounds [32].

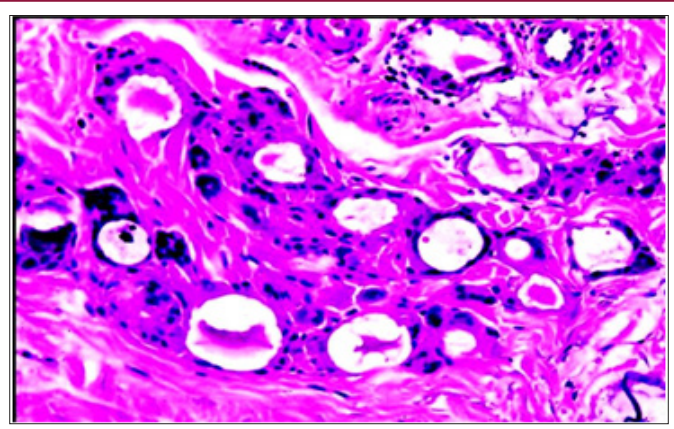

Figure 8: Absorbable dextran beads are surrounded by multinucleated giant cells and granulation tissue at 3 month.

\section{Phagocytosis of Particles}

Phagocytosis, the process by which macrophages recognize and try to destroy or transport wear debris or injected biomaterials, is an essential part of host defense. According to their chemical composition and surface charge, the body reacts either with protein attachment and consequent encapsulation with fibrous tissue [33] or with an attempt to phagocytose the particles. Proteins adsorb to almost all surfaces during the first few minutes of blood or tissue exposure (Figure 3). Its amount, type conformation, and orientation of the bound proteins primarily determine the overall tissue compatibility response of the material. When exposed to foreign body surfaces, the macrophages release cytoplasmic lysosomal content (phospholipases, proteinkinase C, etc.). Intravenously injected particles are either trapped in the lungs or eliminated by the reticuloendothelial system (RES) of the liver if they have a diameter below $10 \mu \mathrm{m}$, e.g. that of a capillary [34-37].

Macrophage activity is affected by the physicochemical state, such as particle size [26,38] chemical structure [8] and surface characteristics [39-40]. A foreign body reaction occurs when size and shape of the implant exceed the diameter of phagocytosable particles (Figure 9). In general, less severe tissue reactions have been observed with powder forms as compared to solid structures of the same material [41]. A sphere has the least surface area for a given volume. Particles with irregular shape and surface have larger and less uniform surfaces, therefore providing more stimulation to the macrophage and initiating release of cytokines. Furthermore, large particles with rough surfaces, which cannot be phagocytosed produce more inflammation. (Figure 9) An increase in surface area allows for increased protein binding in the form of IgM or IgG, leading eventually to increased release of cytokines [15]. 


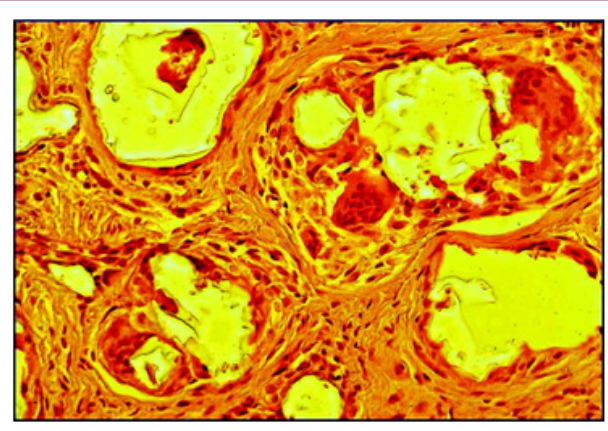

Figure 9: Subdermally injected silicone particles (Macroplastique $\left.{ }^{\circledR}\right)$ stimulate a typical foreign body reaction with giant cells ("frustrated macrophages") at 6 month.

\section{Particle Size}

Macrophages, histiocytes or phagocytes have an average diameter of 15 to $20 \mu \mathrm{m}$. In tissue cultures as well as in living tissue the phagocytosable size of particles is less than $5 \mu \mathrm{m}$ [42]. However, in clinical situations macrophages are able to phagocytose particles and microspheres up to their own size of $15 \mu \mathrm{m}$ and even bigger. Exceptions with phagocytosis of larger particles have been seen occasionally by the formation of multinucleated giant cells [43], which cannot ingest the foreign body by themselves (Figure 9). This unhealthy appetite will cause the death of these converted macrophages with consequent release of intracellular enzymes.

Phagocytosis so far has been described for particles up to a size of $15 \mu \mathrm{m}$ [44]. A raw surface was the prerequisite $[44,45]$. In experiments with mouse peritoneal macrophages [26] the maximal phagocytosis of polystyrene microspheres took place when their size was in the range of $1.0-2.0 \mu \mathrm{m}$. In tissue cultures human leucocytes were not able to eliminate polystyrene spheres with a diameter greater than $7 \mu \mathrm{m}$ by phagocytosis [45]. If larger particles are a stimulus for phagocytosis, the macrophage increases its size and number of nuclei and converts to a multinucleated giant cell (Figure 9). These giant cells can reach a size from $40 \mu \mathrm{m}$ up to $150 \mu \mathrm{m}$ and contain up to 40 nuclei [3].

Eppley [4] calls a giant cell a "frustrated macrophage", since it is not able to transport the foreign material to lymph nodes or liver, even if it was able to ingest it. Because it is not possible for a macrophage of $20 \mu \mathrm{m}$ to transport a $40 \mu \mathrm{m}$ particle, "migration" of these bigger particles can be provided only by mistakenly intravascular injection [46]. In tissue culture, giant cells amass cytoplasm up to a diameter of $150 \mu \mathrm{m}$ by $10 \mu \mathrm{m}$ [47], but are unlikely to be capable of migration. There is a vast amount of orthopedic literature on wear particles from PMMA bone cement or artificial silicone joints, transported to axillary or inguinal lymph nodes. It is generally agreed that small particles of less than $12 \mu \mathrm{m}$ are a critical factor associated with bone resorption [48].

Gonzales [49] compared phagocytosable PMMA particles $(0.325$ and $5.5 \mu \mathrm{m})$ with non-phagocytosable $(200 \mu \mathrm{m})$ spherical particles. Although macrophages appeared to adhere to the big particles, hexosaminidase and PGE2, both markers of macrophage activation, were not stimulated. Therefore, we have to assume that macrophages stop their biological activity as soon as they are full and unable to move. Since the life span of macrophages is very short, i.e. two days only, a constant turnover of these cells must occur within foreign implants. Only phagocytosable PMMA-particles stimulated peritoneal macrophages to secrete interleukin-1 and PGE2 [51]. PMMA-microspheres enhanced human fibroblast proliferative capacity and protein synthesis in vitro. In a test series with PMMA-microspheres of $0.6 \mu \mathrm{m}, 2.0 \mu \mathrm{m}$ and $4.5 \mu \mathrm{m}$ in diameter, cell death occurred only after phagocytosis of 1,250 of the smallest microspheres per cell [51]. The largest PMMA particles from crushed bone cement phagocytosed in-vitro by macrophages were $12 \mu \mathrm{m}$ in diameter. These macrophages released TNF alpha and showed a decreased H3-thymidine uptake compared to inactive cells [48].

Interleukin expression and increased TNF expression was also described by Herman [52] after phagocytosis of PMMA microspheres of $1-2 \mu \mathrm{m}$ in diameter. Gelb [15] showed increased TNF expression after phagocytosis of small PMMA particles of less than $20 \mu \mathrm{m}$ in diameter in a rat's air pouch simulating synovia. Irregular particles produced a greater response in TNF and PGE2 expression than spherical particles of the same size. Particles of $50-350 \mu \mathrm{m}$ in size caused no expression of these factors. PMMA microspheres of $32-40 \mu \mathrm{m}$ in diameter with tiny impurities (Figure 2) on its surface injected subdermally into rats [53] caused a mild foreign body reaction and encapsulation with fibrous tissue within the first weeks (Figure 7). No "migration" of microspheres could be detected in adjacent lymph nodes or distant organs [54,55].

Implantation of washed PMMA microspheres of $32-40 \mu \mathrm{m}$ in diameter with reasonable smooth surface [56,57] caused rarely foreign body reactions $[57,58]$ but immediate phagocytosis, encapsulation with fibroblasts and collagen fibers in humans. Three months after implantation of PMMA-microspheres, one can detect in-growing capillaries, which convert the injectable into a "living implant", which bleeds when cut (Figure 10). Human macrophages of the cell line U 937 phagocytosed high numbers of small PMMAmicrospheres of $4 \mu \mathrm{m}$ and $8 \mu \mathrm{m}$ in diameter, but one microsphere of 20 or $40 \bigotimes \mathrm{m}$ in diameter [59].

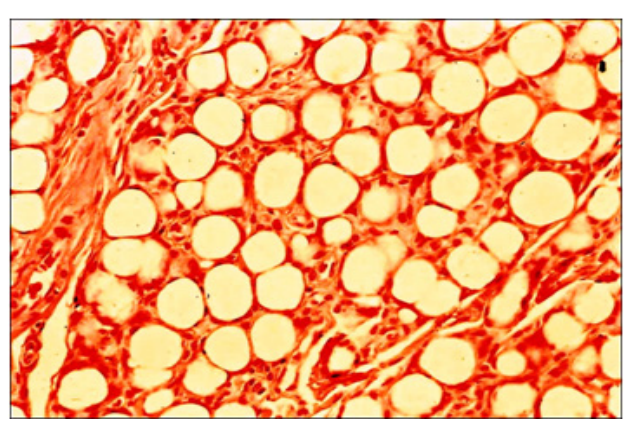

Figure 10: PMMA-microspheres are all encapsulated by macrophages and show in-growing capillaries at 3 month. They have created a "living implant".

\section{Encapsulation of Microspheres}

The diameter of the microspheres plays an important role in determining the amount of fibrous tissue stimulated by the 
injectable implant. From histological pictures (Figure 4) one can assume that each bead is covered outside its ingesting macrophages by a fibrous capsule of about $10 \mu \mathrm{m}$ in width. If one calculates the volume of beads against the volume of connective tissue in a certain volume of implant, roughly $75 \%$ of the permanent volume with $40 \mu \mathrm{m}$ beads consists of the body's own fibrous granulation tissue, whereas the stimulated fibrous tissue around $100 \mu \mathrm{m}$ beads accounts only for approximately 50\% of the permanent implant (Figure 11).

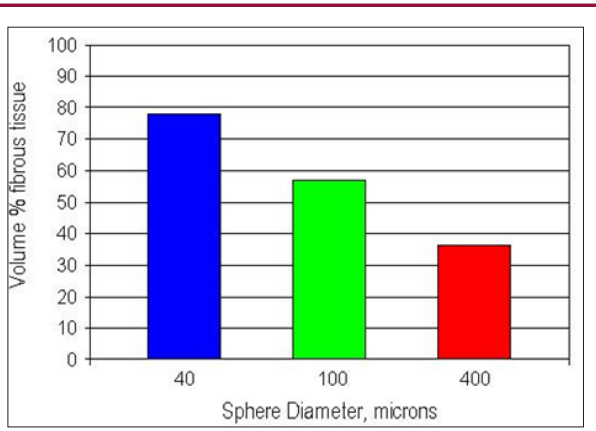

Figure 11: The calculated volume of connective tissue surrounding PMMA-microspheres depends on the size of their size: as bigger they are, as less tissue they generate.

Permanent PMMA-microspheres stimulate an average of $80 \%$ of granulation tissue within the first year (Figure 12), which then converts into pliable scar tissue with predominantly collagen fibers produced by scattered fibroblast. The microspheres are still engulfed - or better: covered - by extremely stretched macrophages, which keep them in place. Multinucleated giant cells cannot be detected anymore (Figure 13). A former transurethral bulking agent, Durasphere ${ }^{\circledR}[60]$, consisted of carbon coated zirconium-oxide beads of $212-500 \mu \mathrm{m}$ in diameter. An 18G needle is necessary in order to deliver 2.5-7.0 cc of these relative big black macrospheres into the delicate periurethral tissue. Another material of microspheres of $120-355 \mu \mathrm{m}$ in diameter, with smooth surface was Bioglass ${ }^{\circledR}$ [61]. Injected around the bladder neck of pigs, no inflammatory response, no foreign body reaction, or migration was detected of the glass beads. However, this little macrophage activity and only tender encapsulation with soft tissue (Figure 4) was the obvious reason for dislocation according gravity in form of a prolapsed [62].

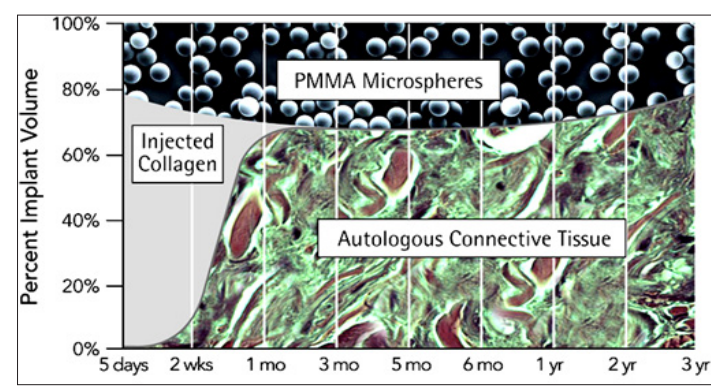

Figure 12: The carrier collagen or carboxy-methylcellulose is absorbed within the first week and leaves the injected PMMA-microspheres packed in the tissue. Slow ingrowth of granulation tissue pushes them apart until a lasting "living implant" is developed.

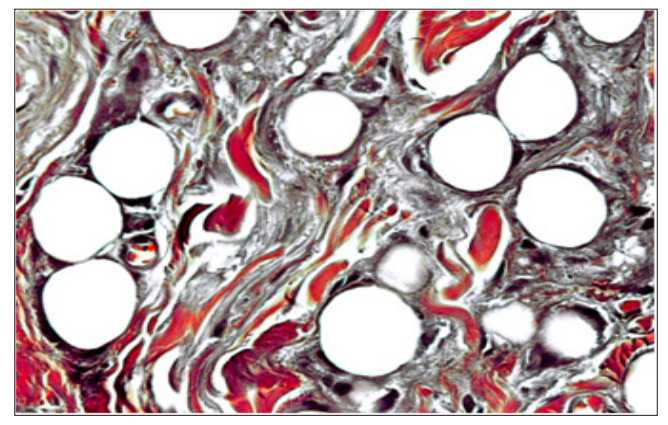

Figure 13: Old PMMA-implant with predominant collagen fibers, scattered fibroblasts and absent giant cells at 10 years. Every microsphere is still enveloped by one or more macrophages.

\section{Transport of Micro Particles}

Silicone particles up to a size of $60 \mu \mathrm{m}$ from wear of a temporomandibular disc were engulfed by giant cells and found in the joint-capsule [63]. After implantation of Swanson ${ }^{\circledR}$ finger joint prostheses, silicone particles up to $65 \mu \mathrm{m}$ were found in the adjacent synovia [64] and up to $45 \mu \mathrm{m}$ particles in giant cells of axillary lymph nodes [65]. Fifteen years after implantation of Swanson ${ }^{\circledR}$ silicone prosthesis for metatarsal-phalangeal joint replacement silicone particles up to a size of 24 to $40 \mu \mathrm{m}$ in diameter were found in an enlarged lymph node of the groin [66]. Of course, these particles or microspheres did not migrate actively, i.e. swim through lymph vessels to lymph nodes but were actively transported by macrophages through lymph or blood vessels [55].

Davis [67] demonstrated the non-toxic nature of PMMA particles $1-100 \mu \mathrm{m}$ in diameter from bone cement (Simplex®) in tissue cultures. Only irregular particles up to a diameter of $50 \mu \mathrm{m}$ were phagocytosed [68]. Small particles less than $5 \mu \mathrm{m}$ had a greater stimulatory effect than particles of non-phagocytosable size $(21-85 \mu \mathrm{m})$ when the same concentration or same number of particles (polystyrene or titanium) was used. Particles larger than $20 \mu \mathrm{m}$ had very little or no stimulatory effect as measured by H3thymidine uptake or cytokine release. In general, many articles on bone cement discuss the chemical inertness and biocompatibility of PMMA [69,70].

Phagocytosis and transport to distant organs has never been reported for Macroplastique ${ }^{\circledR}$ [47], a suspension of $40 \%$ silicone particles in Povidone ${ }^{\circledR}$ PVP, which caused severe granuloma formation in the skin (Figure 9) but less around the urethra. The irregular particles range from $16-400 \mu \mathrm{m}$ and $7 \%$ are less than $50 \mu \mathrm{m}$ [71]. The lesser stimulatory effect of Macroplastique ${ }^{\circledR}$ on foreign body reactions in and around the urethra is certainly due to the highest immunological activity in in the skin compared to internal organs.

A suspension of $50 \%$ dextran beads of $80-120 \mu \mathrm{m}$ in diameter in hyaluronic acid (Deflux®) implanted into the bladder of rabbits demonstrated no distant migration, however [46]. These dextran microspheres caused severe granuloma formation [32,72] until they are resorbed after 1 to 2 years (Figure 8). Burgess [73] used 
positively charged dextran beads of $40-120 \mu \mathrm{m}$ in diameter for the enhancement of wound healing. Macrophages and multinucleated giant cells were found contiguous to the beads, but the authors doubt that they are engulfed (Figure 8).

\section{Foreign Body Granuloma}

In general, particles of biomaterials with rough surface like Teflon ${ }^{\circledR}$ [43], silicone polymer [58], ceramics [74] and those particles with a diameter greater than $20 \mu \mathrm{m}$ cannot be phagocytosed by normal macrophages. Instead, they initiate the formation of a foreign body granuloma. After the implantation of these particles, mononuclear cells from the blood infiltrate the foreign body. Then, mitotic proliferation of cells in blood-vessel walls is seen, followed by an invasion of histiocytes and macrophages. These cells have a short turnover rate of a few hours and phagocytose acceptable particles and bacteria within minutes. Cells laden with particulate matter do not divide, but when they die, their cytoplasmic inclusions are taken up by young histiocytes.

Probably, lymphocytes, which are often called intermediate small round cells, are the progeny of histiocytes [75] and macrophage. The presence of plasma cells indicates that in addition to inflammation an immune response occurs [74]. If particles are too big for phagocytosis by mononuclear cells, these fuse with other macrophages [75] or convert into multinucleated giant cells [4], which are the predominant cell type of a granuloma (Figure 14). Focal aggregates of histiocytes remain active and occasionally epitheloid cells are seen [76]. Giant cells, in general, have a life time of only approximately 1 week [10]. The reaction of the body to the same synthetic may be more or less pronounced in different organs. Immunological reactions are considerable higher in the dermis [77] and subdermis than in bone and muscle [70].

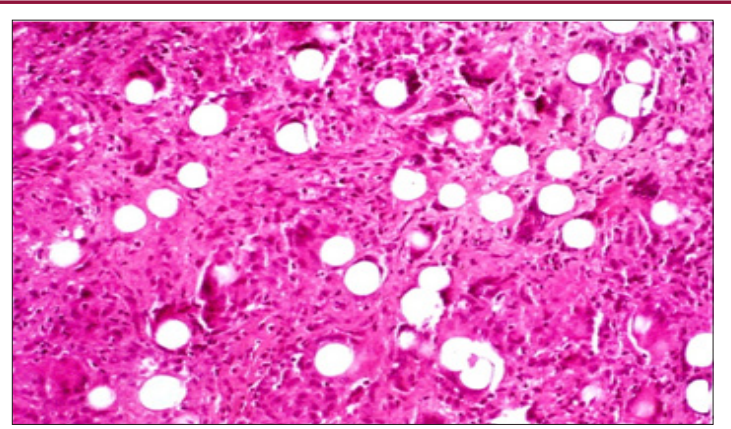

Figure 14: Typical PMMA-granuloma: the microspheres are pushed apart by suddenly invading granulation tissue containing great numbers of macrophages and giant cells. This overreaction can be treated effectively with intralesionally injected corticosteroids [80,81].

Depending on their chemical structure and surface characteristics, most absorbable biological materials and synthetics such as suture materials [78], alginate microspheres [79], polylactic acid, dextran or polymethylacrylate (PMA) particles (Table 2) initiate a temporary foreign body reaction which may remain untreated up to 12 months; whereas granulomas after permanent injectables like PMMA can last up to 5 years $[80,81]$. Polylactic acid (PLLA) particles of a mean diameter of $60 \mu \mathrm{m}, 1.0 \mathrm{~mm}$ and $2.2 \mathrm{~mm}$ respectively, were implanted subcutaneously on the back of rats [82]. They were surrounded by young fibrous tissue from 3 weeks up to 50 weeks and showed fragmentation and phagocytosis by macrophages and foreign body giant cells after 70 weeks of implantation [82]. If implanted intradermally, this reaction may clinically be much more obvious than when implanted subdermally or periurethrally (Figure 15).

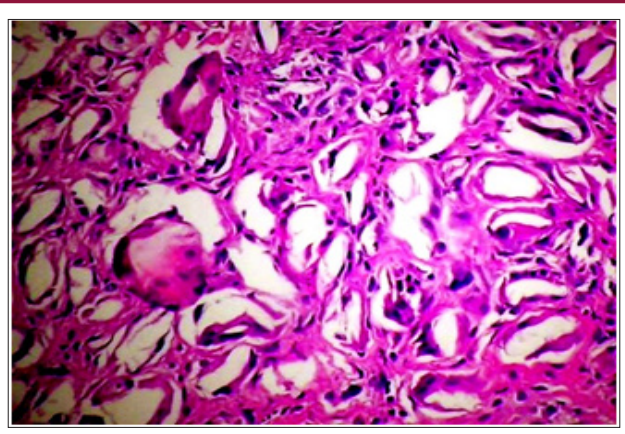

Figure 15: All absorbable particles and microspheres here from PLLA at 6 month - are broken down by tissue enzymes, macrophages and most often giant cells over time. Their clinical effect lasts between 6 and 12 months.

\section{“Migration” of Particles}

Migration of particles is a main issue of artificial joint replacement surgery as well as of injectable bulking agents in urology. In this context, however, migration appears to be misnomer. Particles of biomaterials cannot actively migrate within the body, but have to be phagocytosed by macrophages migrating to lymph nodes or liver, respectively. When trapped in the lungs, they have to be injected accidentally into a venous plexus at the injection site [82]. Of course, extracellular "migration" of particles by mechanical forces such as muscle movement, skin folding, and gravity is a well-known phenomenon. Since it implies no active movement of particles, it should be called correctly "dislocation".

With the exception of injected silicone oil in a very loose skin or gel from ruptured breast implants, which can be pushed along muscle compartments to elbow or groin, the passive mechanical dislocation of microparticles is generally confined to a distance of a few mm. McClelland et al. [54] observed "transepidermal elimination" of PMMA microspheres in guinea pigs. Since this phenomenon was seen on day 3 it must have been due to intraepidermal implantation of the material.

A widely quoted article appeared by Malizia [43], who injected Polytef® (PTFE) paste along the entire length of the urethra through an $18 G$ needle in dogs and monkeys. Polytef $₫$ paste is composed of irregular particles, $90 \%$ being between 4 and $40 \bigotimes \mathrm{m}$ in diameter and $70 \%$ under $20 \mu \mathrm{m}$. Besides granulomatous reactions in pelvic lymph nodes, granulomas were detected in the lungs and other organs, astonishingly, not in the liver. The main particle size in distant organs was 4 to $20 \mu \mathrm{m}$, however, "their greatest dimension ranged from 4 to $80 \mu \mathrm{m}$ ". This sole mention of an $80 \mu \mathrm{m}$ long, irregular PTEF particle in the lung caused the manufacturers of bulking agents for urinary incontinence to produce particles or microspheres larger 
than $100 \mu \mathrm{m}$ in diameter, which was designated the "critical particle size" $(5,6)$.

The diameter of the venous plexus around esophagus and urethra is around $80 \mu \mathrm{m}$, which would allow falsely injected smaller particles or microspheres to swim directly to the lung [6]. The usual migration of macrophages with phagocytosed particles is towards lymph nodes or liver. Knowing the large venous plexus surrounding the urethra, it was suspected that Polytef $\AA$ must have been injected in part intravenously to be taken up by the lungs [81]. Otherwise, the presence of a particle of $80 \mu \mathrm{m}$ in length within a granuloma in the lung cannot be explained. There is absolutely no proof of the statement by Henly [82] that"particles smaller than $80 \mu \mathrm{m}$ have a tendency to migrate". Migration within the body is usually an active process performed by macrophages and exceptionally giant cells, not by inert particles.

Henly [82] injected large $(32-270 \mu \mathrm{m})$ and small $(11-160 \mu \mathrm{m})$ PTFE particles periurethrally in dogs. He found small particles in lymph nodes, lungs, kidneys and brain surface, however, not in liver and spleen. In the lung of one dog, he detected one particle of $65 \mu \mathrm{m}$ length. No particles were found in any of the tissue specimens in the group, which received large $(32-270 \mu \mathrm{m})$ particles. All particles surrounded by giant cells in the lungs were blood-born substances injected into small veins and trapped in the first capillary bed encountered [47,81]. For the purpose of embolization, PMMAmicrospheres of $1 \mathrm{~mm}$ in diameter were injected intra-arterially in patients with intracranial vascular tumors [83]. They did not elicit any inflammatory reaction inside vessels. Dewan [84] described a woman who experienced a skin rash and polyarthropathy 10 days after the removal of a pelvic mass containing a PTFE granuloma of $10 \mathrm{~cm}$ in diameter. Skin biopsy revealed vasculitis containing foreign body giant cells with refractile material consistent with PTFE.

Particulate material may embolize after accidental intravenous injection or intra-operative intrusion into the venous system [86]. Dewan [85] injected PTFE and silicone particles (Macroplastique $®$ ) into rats, but found no foreign material at distant sites after 3 and 6 months, however, a marked local foreign body granuloma reaction was noted (Figure 9). Claes [86] found PTFE particles in the lungs after periurethral implantation. The rapid onset of symptoms and the apparent volume of paste "immigration" indicated that the injection had been in part intravenously. If one looks at the diameter of the urethral venous plexus and imagines a $21 \mathrm{G}$ needle with a diameter of $0.8 \mathrm{~mm}$, intravenous injection appears easily explained. A deadly fat embolism 8 hours after periurethral injection of autogenous fat has been reported. At necropsy many occluded periurethral veins were found [87].

Steyaert [88] described the case of a nine year-old girl whose left kidney had to be removed. At the age of 18 month, a left stage III ureteral reflux had been treated with $0.5 \mathrm{~g}$ of Polytef®. After surgery, the Polytef ${ }^{\circledR}$ could not be detected by ultrasound at the orifice of the ureter and stage III reflux remained. Seven years later, nearly all of the initial $0.5 \mathrm{~g}$ injection was found in a large granuloma occupying the lower pole of the left kidney. One explanation for this event is inadvertent injection into the periureteral veins, which flow into the venous plexus of the renal hilus. A frightening number of $<100$ cases of sudden blindness occurred after accidental injections of collagen, dermal fillers, and fat [90] into the nasolabial and supratrochlear artery. These arteries were filled retrograde and connected with the central retinal artery, which was also occluded.

\section{Potential Carcinogenesis}

Plastic materials have been implanted as solid and as injectable devices. Many studies have investigated the risk of malignancies associated with the implantation of foreign materials in rodents and found that the tumors developed in the capsule around large implants [91] or sheets [92]. However, it has been suggested, that the risk of malignancy is reduced when the implanted foreign body is perforated, and virtually eliminated if the implant is a powdered polymer [41].

Theoretically, sarcomas may arise from chronic granulomatous inflammation as it is caused by irregular particles (Polytef®, Macroplastique ${ }^{\circledR}$ ), foam rubber (polyurethane), or f.i. "textured" breast implants. After silicone fluid injections into rats, $8 \%$ of the animals developed sarcomas [93]. However, no such an event has been reported in humans. The rat is known to have a high incidence of tumor formation when foreign material is implanted under the skin of the back $[92,94]$. The only carcinoma developing in humans with a chronically inflamed, non-healing wound, is Marjolin's ulcer. The present literature on injectable particles and microspheres used for cosmetic purposes [95], bulking agents [96], drug delivery [97] or radiation therapy does not reveal any correlation with or publication on possible tumorigenesis.

\section{Discussion}

The biocompatibility of implant materials is based upon the "fibrous capsule" that envelops the implant. This capsule represents the end stage of a repair process, which begins when plasma proteins contact and adhere to the material during implantation. Various proteins act as chemotactic factors for the infiltration of neutrophils and macrophages [98]. The types of cells present or absent from the interface characterize the nature of the reaction. For example, the absence of lymphocytes at the material interface and from the perivascular region of nearby capillaries implies that the polymer does not elicit an immune response [99].

The late development of massive giant cell formation around an implant must be considered a foreign body granuloma. This has been defined by Spector [75] as giant cells surrounded by palisading macrophages enveloped in a halo of lymphocytes. Macrophages and multinucleated giant cells are the dominant characteristics of the long-term biological response to rough surfaces and particles with irregular shape and surface. Both cell types eliminate foreign body material from the tissue. Since most of the injected irregular particles are too big for phagocytosis and subsequent transport, a chronic rejection process is set in motion, which lasts until the implant is removed.

In contrast to the rough and irregular surface, a monolayer of macrophages surrounded by a zone of fibrous tissue is found 
at the surface of a smooth walled implant or an absolute smooth microsphere. This is the sign of optimal biocompatibility. These microspheres are enveloped with fibroblasts, which remain in a steady state with the implant for the rest of the recipient's life (Figure 3). It seems as if substances with medium size microspheres are able to create the best tissue augmentation in form of fibroblasts and collagen fibers surrounding the microspheres (Figure $10 \& 13$ ), thereby consolidating the bulge implanted beneath the skin, the urethral or esophageal epithelium, respectively.

\section{References}

1. Ersek RA, Beisang AA (1991) Bioplastique: A new textured copolymer microparticle promises permanence in soft-tissue augmentation. Plast Reconstr Surg 87(4): 693-702.

2. Lemperle G, Knapp TR, Sadick NS, Lemperle SM (2010) ArteFill ${ }^{\circledR}$ permanent injectable for soft tissue augmentation: 1.Mechanism of action and injection techniques. Aesth Plast Surg 34(3): 267-272.

3. Lemperle G, Neugebauer P, Kernke R, Lerche KH, Lemperle SM (2017) Microspheres for cosmetic and medical injections must be free of phagocytosable microparticles under 20 microns. Biomed J Sci \& Tech Res 1(6): 1-5.

4. Eppley BL, Summerlin DJ, Prevel CD, Sadove AM (1994) Effects of a positively charged biomaterial for dermal and subcutaneous augmentation. Aesth Plast Surg 18(4): 413-416.

5. Kamler JP, Lemperle G, Lemperle SM, Lehman GA (2010) Endoscopic lower esophageal sphincter bulking for the treatment of GERD: safety evaluation of injectable polymethylmethacrylate microspheres in miniature swine. Gastrointest Endosc 72(2): 332-342.

6. Lemperle G, Lappin P, Stone C, Lemperle SM (2011) Urethral bulking with polymethylmethacrylate microspheres for stress urinary incontinence: Tissue persistence and safety studies in miniswine. Urology 77(4): 10051-10057.

7. Hoffman AS (1984) Synthetic Polymeric Biomaterials. In CG Gebelein, (Eds.) Polymeric Materials and Artificial Organs, Advances in Chemistry Series, Amer Chem Soc, Washington DC, USA, p.13-29.

8. Matsuoka O, Kashima M, Joshima H, Noda Y (1972) Whole-body autoradiographic studies on plutonium metabolism as affected by its physico-chemical state and route of administration. Health Physics 22(6): 713-722.

9. Taylor SR, Gibbons DF (1983) Effect of surface texture on the soft tissue response to polymer implants. J Biomed Mater Res 17(2): 205-227.

10. Coleman DL, King RN, Andrade JD (1974) The foreign body reaction: A chronic inflammatory response. J Biomed Mater Res 8(5): 199-211.

11. Matlage BF, Yasenchak LP, Salthouse TN (1976) Tissue response to implanted polymers: The significance of sample shape. J Biomed Mater Res 10(3): 391-397.

12. Rosengren A, Danielsen N, Bjursten LM (1999) Reactive capsule formation around soft-tissue implants is related to cell necrosis. JBiomed Mater Res 46(4): 458-464.

13. Behling CA, Spector M (1986) Quantitative characterization of cells at the interface of long-term implants of selected polymers. J Biomed Mater Res 20(5): 653-666.

14. Ratner BD, Horbett TA (1984) Protein adsorption to contact lens material. In JM Anderson, (Eds,) Transactions Second World Congress on Biomaterials, Ohio: Society for Biomaterials, Cleveland, USA, 7: 76.

15. Gelb H, Schumacher HR, Cuckler J, Baker DG (1994) In vivo inflammatory response to polymethylmethacrylate particulate debris: effect of size, morphology, and surface area. J Orthop Res 12(1): 83-92.
16. Ross S, Morrison ID (1988) Size and surface area. In Colloidal Systems and Interfaces. John Wiley, New York, USA, p. 31-43.

17. Borchard G, Kreuter J (1993) Interaction of serum components with poly (methylmethacrylate) nanoparticles and the resulting body distribution after intravenous injection in rats. J Drug Targeting 1(1): 15-19.

18. Hallab NJ, Bundy KJ, O’Connor K, Clark R, Moses RL (1995) Cell adhesion to biomaterials: Correlation between surface charge, surface roughness, adsorbed protein, and cell morphology. J Long-Term Effects Med Implants 5(3): 209-231.

19. Seno S, Tanaka A, Urata M, Hirata K, Nakatsu H, et al. (1975) Phagocytic response of rat liver capillary endothelial cells and Kupffer cells to positive and negative charged iron colloid particles. Cell Struct Funct 1(1): 119-127.

20. Nagura H, Asai J, Kojima K (1977) Studies on the mechanism of phagocytosis. I. Effect of electric surface charge on phagocytic activity of macrophages for fixed red cells. Cell Struct Funct 2: 21-25.

21. Kapur R, Lilien J, Black J (1993) Field-dependent fibroblast orientation on charged surfaces in independent of polarity and adsorbed serum proteins. Biomaterials 14(11): 854-860.

22. Absolom DR, Thomson C, Hawthorn LA, Zingg W, Neumann AW (1988) Kinetics of cell adhesion to polymer surfaces. J Biomed Mater Res 22(3): 215-229.

23. Ratner BD, Johnston AB, Lenk TJ (1987) Biomaterial surfaces. J Biomed Mater Res 21: 59-89.

24. Tabata Y, Ikada Y (1988) Effect of size and surface charge of polymer microspheres on their phagocytosis by macrophages. Biomaterials $9(4)$ : 356-362.

25. Baier RE (1988) Advanced biomaterials development from natural products. J Biomat Applic 2(4): 615-626.

26. Baier RE (1992) Principles of adhesion. Operat Dentistry Suppl 5:1-9.

27. Andrade JD (1972) Interfacial phenomena and biomaterials. Med Instrument 7: 110-115.

28. Lykema J (1985) Interfacial electrochemistry of surfaces with biomedical relevance. In: J.D. Andrade (Eds.) Surface and Interfacial Aspects of Biomedical Polymers, Vol. I. New York, Plenum Press, USA, pp.293-334.

29. Krukowski M, Eppley B, Mustoe T, Osdoby P (1991) Hard and soft connective tissue growth and repair in response to charged surfaces. In: J.E. Davies (Eds,) The Bone-Biomaterial Interface. Toronto: University of Toronto Press, USA, pp. 275.

30. Lacasse FX, Filion MC, Phillips NC, Escher E, McMullen JN, et al. (1998) Influence of surface properties at biodegradable microsphere surfaces: Effects on plasma protein adsorption and phagocytosis. Pharmaceut Res 15: 312-317.

31. Krukowski M, Snyders RV, Eppley BL, Simmons DJ (1994) Negatively charged resins stimulate bone formation in subperiosteal sites in rats. Clin Orthop Related Res 298: 266-271.

32. Mustoe TA, Weber DA, Krukowski M (1992) Enhanced healing of cutaneous wounds in rats with positively charged surfaces. Plast Reconstr Surg 89: 891-897.

33. Nathanson D, Gettleman L, Shnitman P, Sklar G (1978) Histologic response to porous PMMA implant materials. J Biomed Mater Res 12(1): 13-33.

34. Juhlin L (1960) Retention of particles by the reticuloendothelial system. Acta Physiol Scand 48: 78-87.

35. McLaughlin RE, DiFacio CA, Hakala M, Abbott B, MacPhail JA, et al. (1973) Blood clearance and acute pulmonary toxicity of methylmethacrylate in dogs after simulated arthroplasty and intravenous injection. J Bone Joint Surg 55(8): 1621-1628. 
36. Lemperle G (1970) Depression and stimulation of host defense mechanisms after severe burn. Plast Reconstr Surg 45(5): 435-440.

37. Lemperle G, Reichelt M (1973) Der Lipofundin-Clearance Test. Med Klin 68: 48-53.

38. Zilversmit DB, Boyd GA, Brucer M (1972) The effect of particle size on blood clearance and tissue distribution of radioactive gold colloid. J Lab Clin Med 40(2): 255-260.

39. Shanbhag AS, Jacobs JJ, Black J, Galante J0, Glant TT (1994) Macrophage/ particle interactions: Effect of size, composition and surface area. J Biomed Mater Res 28(1): 81-90.

40. Watanabe K, Nagura H (1981) Structural and functional changes of macrophages in self-defensive function. Taisha 18: 1297-1304.

41. Oppenheimer ET, Willhite M, Danishefsky J, Stout AP (1961) Observations on the effects of powdered polymer in the carcinogenic process. Cancer Res 21: 132-134.

42. Glant TT, Jacobs JJ, Molnar G, Shangbhag AS, Valyon M, et al. (1993) Bone resorption activity of particulate-stimulated macrophages. J Bone Mineral Res 8(9): 1071-1079.

43. Malizia AA, Reiman HM, Myers RP, Sande RP, Barham JR, et al. (1984) Migration and granulomatous reaction after periurthral injection of Polytef (Teflon). JAMA 251(4): 3277-3281.

44. Pratten MK, Lloyd JB (1986) Pinocytosis and phagocytosis: the effect of size of a particulate substrate on its mode of capture by rat peritoneal macrophages cultured in vitro. Biochim Biophys Acta 881(3): 307-313.

45. Roberts J, Quastel JH (1963) Particle uptake by polymorphonuclear leucocytes and Ehrlich ascites-carcinoma cells. Biochem J 89(1): 150156.

46. Stenberg AM, Sudin A, Larsson BS, Laeckgren G, Stenberg A (1997) Lack of distant migration after injection of a 125-iodine labeled dextranomer based implant into the rabbit bladder. J Urol 158: 1937-1941.

47. Solomon LZ, Birch BR, Cooper AJ, Davies CL, Holmes SAV (2000) Nonhomologous bioinjectable materials in urology: 'size matters"? Brit J Urol Int 85: 641-645.

48. Horowitz SM, Doty SB, Lane JM, Burstein AH (1993) Studies of the mechanism by which the mechanical failure of polymethylmethacrylate leads to bone resorption. J Bone Joint Surg 75(6): 802-813.

49. Gonzales O, Smith RL, Goodman SB (1996) Effect of size, concentration, surface area, and volume of polymethylmethacrylate particles on human macrophages in vitro. J Biomed Mater Res 30(4): 463-473.

50. Glant TT, Jacobs JJ (1994) Response of three murine macrophage populations to particulate debris: Bone resorption in organ cultures. J Orthop Res 12(5): 720-731.

51. Catelas I, Huk OL, Petit A, Zukor DJ, Marchand R, et al. (1998) Flow cytometric analysis of macrophage response to ceramic and polyethylene particles: effect of size, concentration, and composition. J Biomed Mater Res 15: 600-607.

52. Herman JH, Sowder WG, Anderson D, Appel AA, Hopson CN (1989) Polymethylmethacrylate-induced release of bone-resorbing factors. Bone Joint Surg 71(10): 1530-1541.

53. Lemperle G, Ott H, Charrier U, Hecker J, Lemperle M (1991) PMMA microspheres for intradermal implantation. Part I. Animal research. Ann Plast Surg 26: 57-63.

54. McClelland M, Egbert B, Hanko V, Berg RA, DeLustro F (1997) Evaluation of Artecoll polymethylmethacrylate implant for soft-tissue augmentation: Biocompatibility and chemical characterization. Plast Reconstr Surg 100(6): 1466-1474.

55. Lemperle G, Morhenn VB, Pestonjamasp V, Gallo R (2004) Migration studies and histology of injectable microspheres of different size in mice. Plast Reconstr Surg 113: 1380-1390.
56. Lemperle G, Sadick NS, Knapp TR, Lemperle SM (2010) ArteFill ${ }^{\circledR}$ permanent injectable for soft tissue augmentation: 2. Indications and applications. Aesth Plast Surg 34(3): 273-286.

57. Li D, Luo SK, Wang YC, Lemperle G (2017) Facial volume restoration with permanent dermal filler (Artecoll-4) in Chinese women. Facial Plast Surg 33(5): 537-544.

58. Vent J, Lemperle G (2014) Prevention and treatment of complications after polymethylmethacrylate microspheres injections. Facial Plast Surg 30: 628-634.

59. Morhenn V, Lemperle G, Gallo R (2002) Phagocytosis of different particulate dermal filler substances by human macrophages and skin cells. Dermatol Surg 28(6): 484-490.

60. Lightner D, Calvosa C, Andersen R, Klimberg I, Brito CG, et al. (2001) A new injectable bulking agent for treatment of stress urinary incontinence: results of a multicenter, randomized, controlled, doubleblind study of Durasphere. Urology 58(1): 12-15.

61. Walker RD, Wilson J, Clark AE (1992) Injectable Bioglass as a potential substitute for injectable polytetrafluoroethylene. J Urol 148: 645-647.

62. Ghoniem GM, Khater U (2006) Urethral prolapse after Durasphere injection. Int Urogynecol J Pelvic Floor Dysfunct 17: 297-298.

63. Dolwick MF, Aufdemorte TB (1985) Silicone-induced foreign body reaction and lymphadenopathy after temporomandibular joint arthropathy. Oral Surg 59(5): 449-452.

64. Christie AJ, Weinberger KA, Dietrich M (1977) Silicone lymphadenopathy and synovitis. JAMA 237(14): 1463-1464.

65. Kircher T (1980) Silicone lymphadenopathy: A complication of silicone elastomer finger joint protheses. Human Pathol 11(3): 240-244.

66. Pe'oc'h M, Duprez D, Grice G, Fabre-Bocquentin B, Gressin R, et al. (2005) Silicone lymphadenopathy mimicking a lymphoma in a patient with a metatarsophalangeal joint prosthesis. J Clin Pathol 53: 549-551.

67. Davis RG, Goodman SB, Smith RL, Lerman JA, Williams RJ (1993) The effect of bone cement powder on human adherent monocytes/ macrophages in vitro. J Biomed Mater Res 27(8): 1039-1046.

68. Murray DW, Rushton N (1990) Macrophage stimulate bone resorption when they phagocytose particles. J Bone Joint Res 72-B: 988-992.

69. Convery FR, Gunn DR, Hughes D, Martin WE (1975) The relative safety of polymethylmethacrylate. J Bone Joint Surg 57(1): 57-64.

70. Apple DJ, Mamalis N, Brady SE, Loftfield K, Kavka-van Norman D, et al. (1984) Biocompatibility of implant materials: A review and screening electron microscopic study. Am Intra-Ocular Implant Soc J 10(1): 53-66.

71. Smith DP, Kaplan WE, Ryoichi O (1994) Evaluation of polymethylsiloxane as an alternative in the endoscopic treatment of vesicoureteral reflux. J Urol 152(4): 1221-1224.

72. Stenberg A, Larsson E, Lindholm A, Ronneus B, Stenberg A, et al. (1999) Injectable dextranomer-based implant: histopathology, volume changes and DNA-analysis. Scand J Urol Nephrol 33: 355-361.

73. Burgess E, Hollinger J, Bennett S, Schmitt J, Buck D, et al. (1998) Charged beads enhance cutaneous wound healing in rhesus non-human primates. Plast Reconstr Surg 102(7): 2395-2403.

74. Semmelink JM, Klein CP, Vermeiden JP, Althuis AL (1986) Granuloma and plasma cell formation induced by the subcutaneous implantation of b-whitlockite particles. Biomaterials 7(2): 152-154.

75. Spector WG, Lykke AWJ (1966) the cellular evolution of inflammatory granulomata. J Pathol Bact 92(1): 163-167.

76. Hirsch BC, Johnson WC (1984) Concept of granulomatous inflammation. Nt J Dermatol 23(2): 90-100.

77. Lemperle G (1976) inflammatory reactions to intradermal dexon sutures. In: Marchac D \& Hueston JT (Eds.). Transactions of the 6th 
International Congress on Plastic and Reconstructive Surgery. Masson, Paris, p. 28-34.

78. Marler JJ, Guha A, Rowley J, Koka R, Mooney D, et al. (2000) Soft-tissue augmentation with injectable alginate and syngeneic fibroblasts. Plast Reconstr Surg 105(6): 2049-2058.

79. Lemperle G, Gauthier-Hazan N, Wolters M, Eisemann-Klein M, Zimmermann U, et al. (2009) foreign body granulomas after all injectable dermal fillers. Part 1: Possible causes. Plast Reconstr Surg 123(6): 18421863.

80. Lemperle G, Gauthier-Hazan N (2009) foreign body granulomas after all injectable dermal fillers. Part 2: Treatment options. Plast Reconstr Surg 123(6): 1864-1876.

81. Bergsma JE, Rozema FR, Bos RRM, Boering G, De Bruijn WC, et al. (1995) In vivo degradation and biocompatibility study of in vitro pre-degraded as-polymerized polylactide particles. Biomaterials 16(4): 267-274.

82. Henly DR., Barrett DM, Weiland TL, O'Connor MK, Malizia AA, et al. (1995) Particulate silicone for use in periurethral injections, local tissue effects, and search for migration. J Urol 153(6): 2039-2043.

83. Radhkrishnan VV, Saraswathy A, Rao VR, Jayakrishnan A, Rout D (1992) Histopathological evaluation of polymethylmethacrylate as an embolic agent. Acta Neurochir 117(1-2): 30-33.

84. Dewan PA, Fraundorfer M (1996) Skin migration following periurethral polytetrafluoroethylene injection for urinary incontinence. Aust N Z J Surg 66(1): 57-59.

85. Dewan PA, Byard RW (1994) Histological response to injected Polytef and Bioplastique in a rat model. Brit J Urol 73(4): 370-376.

86. Claes H, Stroobants D, Van Meerbeek J, Verbeken E, Knockaert D, et al. (1989) Pulmonary migration following periurethral polytetrafluoroethylene injection for urinary incontinence. J Urol 142(3): 821-822.

87. Currie I, Drutz HP, Deck J, Oxorn D (1997) Adipose tissue and lipid droplet embolism following periurethral injection of autologous fat: Case report and review of the literature. Int Urogynecol J 8(6): 377-380.
88. Steyaert H, Sattonet C, Bloch C, Jaubert F, Galle P, et al. (2000) Migration of PTFE paste particles to the kidney after treatment for vesico-ureteric reflux. Brit J Urol Int 85(1): 168-169.

89. Beleznay K, Carruthers JD, Humphrey S, Jones D (2015) Avoiding and treating blindness from fillers: A review of the world literature. Dermatol Surg 41(10): 1097-1117.

90. Oppenheimer BS, Oppenheimer ET, Danishefsky I, Stout AP, Eirich FR (1955) further studies of polymers as carcinogenic agents in animals. Cancer Res 15(5): 333-340.

91. Laskin DM, Robinson IB, Weinmann JP (1954) Experimental production of sarcomas by methyl methacrylate implants. Proc Soc Exp Biol Med 87: 329-332.

92. Hueper WC (1959) Carcinogenic studies on water-soluble and insoluble macromolecules. Arch Path 67(6): 589-617.

93. Hueper WC (1964) Cancer induction by polyurethane and polysilicone plastics. J Natl Cancer Inst 33(6): 1005-1027.

94. Lemperle G, Morhenn VB, Charrier U (2003) Human histology and persistence of various injectable filler substances for soft tissue augmentation. Aesth Plast Surg 27(5): 354-366.

95. Lemperle G, Lemperle SM (2017) Injectable bulking agents for the treatment of stress urinary incontinence. SM Gerontol Geriatr Res 1(1): 1005.

96. Bettencourt A, Almeida AJ (2012) Poly (methyl methacrylate) particulate carriers in drug delivery. J Microencapsul 29(4): 353-367.

97. Zandstra J, Hiemstra C, Petersen AH, Zuidema J, Van Beuge MM, et al. (2014) Microsphere size influences the foreign body reaction. Eur Cell Mater 28(28): 335-347.

98. Sheikh Z, Brooks PJ, Barzilay O, Fine N, Glogauer M (2015) Macrophages, Foreign Body Giant Cells and Their Response to Implantable Biomaterials. Materials (Basel) 8(9): 5671-5701.

99. Klopfleisch R, Jung F (2017) the pathology of the foreign body reaction against biomaterials. J Biomed Mater Res A 105(3): 927-940.

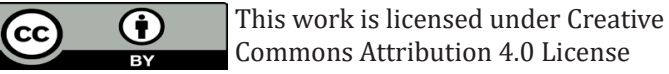

Submission Link: http://biomedres.us/submit-manuscript.php

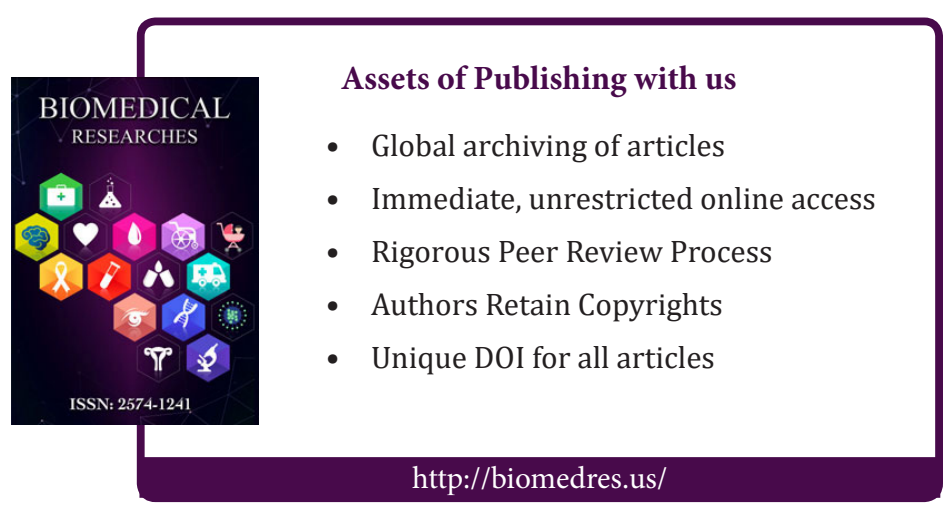

